Научная статья /

Research Article

УДК 821.І6І.І.о

ББК $83.3(2 \mathrm{Poc}=\mathrm{Pyc}) 6$
ПРЕОДОЛЕНИЕ ФАУСТА: ТВОРЧЕСТВО А.М. ГОРЬКОГО В ОЦЕНКЕ ФИЛОСОФА, ПОЭТА, ЭСТЕТИКА А.К. ГОРСКОГО

\author{
(C) 202I г. А.Г. Гачева \\ Институт мировой литературы им. А.М. Горького \\ Российской академии наук, \\ Москва, Россия \\ Дата поступления статьи: ог марта 202I г. \\ Дата одобрения рецензентами: 29 апреля 2021 г. \\ Дата публикации: 25 декабря 2021 г. \\ https://doi.org/IO.22455/2500-4247-202I-6-4-3I4-343
}

Исследование выполнено в Институте мировой литературы им. А.М. Горького РАН за счет гранта Российского научного фонда (РНФ, проект № I7-I8-ог432-П)

Аннотация: В статье рассматривается отношение философа, поэта, эстетика А.К. Горского к личности и наследию А.М. Горького. Показано, что Горский выдвигает на первый план активность и проективность творческого мышления Горького, считает его последовательным имморталистом. В центре внимания - неопубликованная работа Горского «Преодоление Фауста» (1939-1940), представляющая собой характерный образец философской критики художественного произведения, использующей и филологические приемы анализа. Горский рассматривает фаустианство сквозь призму неприятия индивидуализма, характерного для творчества Горького. Считая определяющей чертой фаустианского сознания стремление к знанию и действию, Горский отмечает, что это стремление сковано и ограничено фактом человеческой смертности, признанием всесилия стихийной природы. Тот факт, что фаустианство не претендует на преодоление смерти, фактически примиряется с ней, позволяет Горскому сблизить его с мещанским типом сознания. Горький, воздвигавший протест против мещанской пассивности, ставит своим творчеством вопрос о преодолении смерти. Ранняя сказка Горького «Девушка и смерть» трактуется Горским в контексте становления жизнеутверждающего сознания, которое побеждает смерть силой любви и общим делом.

Ключевые слова: литературно-философское наследие А.К. Горского, творчество А.М. Горького, работа «Преодоление Фауста», критика фаустианского сознания, активизм, проективность, иммортализм, философская критика мещанства, индивидуализм, коллективизм.

Информация об авторе: Анастасия Георгиевна Гачева - доктор филологических наук, ведущий научный сотрудник, Институт мировой литературы им. А.М. Горького Российской академии наук, ул. Поварская, д. 25 а, І2Іо69 г. Москва, Россия. ORCID ID: https://orcid.org/oooo-oooI-5453-088I

E-mail: a-gacheva@yandex.ru

Для цитирования: Гачева А.Г. Преодоление Фауста: творчество А.М. Горького в оценке философа, поэта, эстетика А.К. Горского // Studia Litterarum. 202I. T. 6, № 4 . C. 3I4-343. https://doi.org/IO.22455/25OO-4247-2O2I-6-4-3I4-343 


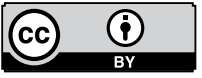

This is an open access article distributed under the Creative Commons Attribution 4.0 International (CC BY 4.0)

Studia Litterarum, vol. 6, no. 4, 202I

\section{OVERCOMING FAUST: MAKSIM GORKY IN THE PERCEPTION OF PHILOSOPHER, POET, AND AESTHETICIAN ALEKSANDR GORSKY}

(C) 202I. Anastasia G. Gacheva

\author{
A.M. Gorky Institute of World Literature \\ of the Russian Academy of Sciences, \\ Moscow, Russia \\ Received: March OI, 2O2I \\ Approved after reviewing: April 29, 202I \\ Date of publication: December 25, 202I
}

Acknowledgements: The research has been carried out at A.M. Gorky Institute of World Literature of the Russian Academy of Sciences supported by the Russian Science Foundation grant (RSF, project no. I7-I8-OI432-П).

Abstract: The article examines the attitude of philosopher, poet, and aesthetician Aleksandr Gorsky to the personality and legacy of A.M. Gorky. It outlines the main directions of Gorky's perception and interpretation by Gorsky. The article argues that Gorsky highlights vitality and projectivity of Gorky's creative thinking, and considers him a consistent immortalist. The focus is on Gorsky's unpublished work "Overcoming Faust” (I939-I940), a typical example of philosophical criticism that uses philological methods of analysis. Gorsky examines Faustianism through the prism of the rejection of individualism, which is specific for Gorky's work. Considering the desire for knowledge and action as the defining feature of the Faustian consciousness, Gorsky notes that this desire is constrained and limited by the fact of human mortality and the recognition of the omnipotence of nature. The fact that Faustianism does not aim at overcoming death and eventually comes to terms with with it, allows Gorsky to see Faustianism as a bourgeois type of consciousness. Instead, Gorky, by standing against petty-bourgeois passivity in his work, raises the question about the means to overcome death. Gorky's early fairy tale "The Girl and Death" is interpreted by Gorsky in the context of the development of life-affirming consciousness that overcomes death by the power of love and devotion to the common cause.

Keywords: literary and philosophical heritage of Aleksandr Gorsky, Maksim Gorky's work, "Overcoming Faust," criticism of the Faustian consciousness, activism, projectivity, immortalism, philosophical criticism of philistinism, individualism, collectivism.

Information about the author: Anastasia G. Gacheva, DSc in Philology, Leading Research Fellow, A.M. Gorky Institute of World Literature of the Russian Academy of Sciences, Povarskaya 25 a, I2I069 Moscow, Russia. ORCID ID: https://orcid.org/o0oo-o0oI-5453-088I

E-mail: a-gacheva@yandex.ru

For citation: Gacheva, A.G. "Overcoming Faust: Maksim Gorky in the Perception of Philosopher, Poet, and Aesthetician Aleksandr Gorsky." Studia Litterarum, vol. 6, no. 4, 202I, pp. 3I4-343. (In Russ.) https://doi.org/IO.22455/2500-4247-202I-6-4-3I4-343 
Философ, эстетик, поэт Александр Константинович Горский (г886-1943) фигура, еще недостаточно известная горьковедам. И этому есть свое объяснение. Хотя творчество А.М. Горького находилось в орбите заинтересованного внимания Горского почти два десятилетия, однако большинство его текстов, посвященных Горькому, до сих пор остаются в архивах. В 2004 г. в сборнике «А.М. Горький и его корреспонденты» в научный оборот были введены письма А.К. Горского и его друга и единомышленника Н.А. Сетницкого к А.М. Горькому [2], в первом томе антологии «Н.Ф. Федоров: pro et contra» был републикован с купюрами очерк Горского «Острие мирового кризиса», являющийся четвертой частью его работы «Николай Федорович Федоров и современность» и содержащий обширные апелляции к Горькому [I3]. В 2018 г. вышло в свет двухтомное издание сочинений и писем Горского, включившее и его письма Сетницкому г926-г928 гг., в которых обсуждаются детали контактов друзей-единомышленников с Горьким, и корпус писем Горского его духовным ученицам О.Н. Сетницкой и Е.А. Крашенинниковой I937-г943 гг., проливающих свет на занятия Горского горьковской темой в І939-г940 гг. Однако до сих пор не опубликованы посвященные Горькому работы Горского І938-г940 гг., и прежде всего обширная статья «Преодоление Фауста» (1939-1940), главная в его философской горьковиане. Эта статья, созданная на стыке филологии и философии, синтезирует методы той и другой, представляя яркий пример взаимодействия литературы и философской мысли, характерного для русской культуры XIX-XX вв. [4; 5; 6]. 


\section{Становление горьковской темы в творчестве А.К. Горского}

В дореволюционном творчестве А.К. Горского интерес к фигуре А.М. Горького не просматривается. Выпускник Московской духовной академии, судьба которого отчасти оказалась схожа с судьбой Алеши Карамазова (по благословению монаха-схимника он ушел в мир), молодой поэт и мыслитель в І900-І9Іо-е гг. всецело погружен в религиозно-философскую проблематику. Его кумиры - Ф.М. Достоевский, Н.Ф. Федоров, В.С. Соловьев, апологеты творческого, миропреображающего христианства. И сам он жаждет религиозной активности в мире, Царства Божия на земле, а не в потусторонности, и воспринимает обетование о победе над смертью как заповедь роду людскому. Наследуя эстетике Федорова и Соловьева, Горский видит в искусстве силу воскресительную и жизнетворческую, ищет пути расширения символистской теории творчества, призывая двигаться от «мировосприятия» к «творческому мировоздействию», от утверждения реальнейшего к преображению реального. В предисловии к своему первому поэтическому сборнику «Глубоким утром» (I9I3), которое стало первой ласточкой его концепции литургизма в литературе, А.К. Горский писал: «Если символизм в поэзии - сочетание, сопричастие многих Одному, то он не может и не должен довольствоваться единомыслием и единочувствием, но хочет и требует единодействия» [I4, кн. I, с. І29].

Впрочем, именно эта жажда реального христианского делания, стремление не просто верить во Христа, но и творить Его дела, не просто чаять «воскресения мертвых и жизни будущего века», но и осуществлять их в реальности, религиозный активизм А.К. Горского готовил почву для будущей духовной встречи с А.М. Горьким, богостроительство которого было утверждением религиозной активности человека-творца, соединенного с другими в коллективный организм народа, нации, человечества. И недаром в записных книжках А.К. Горского - как бы в pendant заявленному в программной горьковской статье «Разрушение личности» (1909) тезису об источной связи творчества с коллективной энергией народа ${ }^{\mathrm{I}}$ о том, что во всякий подлинный шедевр есть создание «коллективного опыта», несет

I «Народ не только сила, создающая все материальные ценности, он - единственный и неиссякаемый источник ценностей духовных, первый по времени, красоте и гениальности творчества философ и поэт, создавший все великие поэмы, все трагедии земли и величайшую из них - историю всемирной культуры» [18, т. 24, с. 26]. 
в себе дух народных масс, появляется размышление о поэме Н.А. Некрасова «Коробейники», в которой молодой Горский видит образец именно такого, синергийного творчества художника и коллективной народной души: «...единственное произведение нашей поэзии - за 200 лет - дошедшее до народа - и слившееся с ним! Уж по одному этому - можно догадываться, что его мистика - необъятна - символика огненна... и многозначимость неисчерпаема. И здесь - Дионис - русский в Некрасове - поэте скудости - по преимуществу - творит из полноты... полна, полна коробушка! Мысль - изреченная не вмещает наших чувств - и вот слова заменяются мимикой <...> - и аккомпанемент - хора - искусной музыки - на мотив народной песни, то есть - как бы гудение всего народа, показывающее, что события драмы происходят на фоне народной души, что герои не отъединены от вселенских истоков трагизма, но связаны невидимо крепкими нитями со всеми вот колосьями, березами и толпами сударушек-варварушек» [I4, КH. I, C. 22].

Спустя тридцать лет, в работе «Преодоление Фауста» А.К. Горский специально обратится к статье «Разрушение личности», подчеркивая, что в ней А.М. Горький точно и убедительно представляет «законы взаимоотношений коллективной и индивидуальной художественной фантазии» [15, c. 5]. При этом он особенно отметит утверждение Горького о сопротивлении смерти как точке приложения коллективных энергий рода, о воскресительном импульсе, лежащем в основе первобытного человечества, - утверждение, сближающее писателя с философом «всеобщего дела» Н.Ф. Федоровым, адептом которого А.К. Горский был долгие годы: «..печаль об утрате части своей физической энергии, опасение новых потерь, желание оградить себя от них, противопоставить силе смерти всю силу сопротивления коллектива, естественное желание борьбы с ней, мести ей < ...> слагались в единое бессознательное, но необходимое и напряженное желание заместить убыль, воскресить отшедшего, оставить его в своей среде» [І8, т. 24, с. 28].

Последовательное неприятие смерти, непризнание компромиссов в отношении к «курноске», которым так охотно отдавал дань Л.Н. Толстой [35, т. 4, с. 34; І4, кн. І, с. 647-648], стало той почвой, на которой возникало и росло внимание Горского к творчеству Горького. Свою роль сыграло и знакомство с «Воспоминаниями» писателя, в частности с очерком «Лев Толстой», и особенно с фрагментом этого очерка, напечатанным в журна- 
ле «Беседа» (1923. Май-июнь, № I). На эти воспоминания А.К. Горский позднее будет опираться в брошюре «Перед лицем смерти. Л.Н. Толстой и Н.Ф. Федоров» (Харбин, І928), концепция которой фактически вырастет из характеристики, данной Толстому Горьким: человек, который «с величайшим напряжением всех сил духа своего одиноко всматривается в самое главное: в смерть» [18, т. I4, с. 280]. Эту характеристику А.К. Горский назовет «самой острой и меткой» из «всех характеристик, данных Льву Николаевичу людьми, лично его знавшими» [І4, кн. I, с. 649].

Углублению интереса к фигуре А.М. Горького способствовали и внешние обстоятельства. Переехав в Москву в 1922 г., А.К. Горский общается с А.Д. Кожевниковой, вдовой друга, ученика и издателя сочинений Н.Ф. Федорова В.А. Кожевникова, которая сообщает ему об интересе писателя к идеям Федорова. Те же сведения он, по его собственному свидетельству, получает и «из других источников» [2, с. 524]. Взяв на заметку эти сведения, А.К. Горский г9 марта І923 г. обращается с письмом к А.М. Горькому, предлагая ряд проектов, связанных с публикацией хрестоматии из произведений мыслителя и разработкой литературно-философских тем «Федоров и Толстой», «Федоров и Достоевский» [2, с. 524]. А затем внимательно следит за начавшейся в 1926 г. перепиской Н.А. Сетницкого, осенью 1925 г. уехавшего на службу в Харбин, с Горьким, давая советы своему младшему другу, стремившемуся подвигнуть писателя заявить о федоровских идеях публично [І4, кн. 2, с. 392, 415-420, 423, 428, 431 и др.].

Внимание к Горькому было связано и с той внутренней установкой, которую в начале г920-х гг. избирают Н.А. Сетницкий и А.К. Горский по отношению к советской власти и ее лозунгам. Сознавая глубинные изъяны большевистской идеологии, шаткость ее нравственных оснований, они стремятся расширить духовную платформу нового строительства, выставить против идеологем революции иную, онтологическую систему ценностей, подобно Н.Ф. Федорову заменяют «вопрос о богатстве и бедности» «вопросом о смерти и жизни» [35, т. І, с. 390]. Узкому масштабу власти, стоящей на классовой точке зрения, противопоставляют глобальный масштаб учения «всеобщего дела», касающегося всех и каждого вне зависимости от социального статуса и политических убеждений.

Попытку расширить узкий горизонт марксистской доктрины А.К. Горский сделал еще в І9І3 г. в предисловии к сборнику «Вселенское 
Дело», вводившему идеи Н.Ф. Федорова в контекст современности, подчеркнув, что сопротивление смерти есть дело, «способное объединить в себе все дела человеческие», и выдвинув лозунг, построенный по типу известного пролетарского лозунга «Манифеста коммунистической партии»: «Смертные всех стран, племен, народов, всех занятий, званий, состояний, всех верований, мнений, убеждений, - соединяйтесь!» [I4, кн. I, с. I48]. Тот же лозунг «Смертные всех стран, соединяйтесь!», переводящий вопрос о причинах зла и несправедливости в мире из социального в онтологический план, призыв «всех, без различия пола, возраста, расы, класса, вероисповедания и мировоззрения, на борьбу с врагом извечным и сильным, но победимым и побеждаемым» [12, с. 369], А.К. Горский и Н.А. Сетницкий повторили в проспекте к планировавшему в І920 г., но так и не изданному тогда второму выпуску «Вселенского Дела» и однодневной газете «На помощь!», которую выпустили в Одессе в связи с «голодной катастрофой» этого года [3I, c. 205]. Они настаивали на необходимости преодолеть узкий взгляд на главную причину неравенства, бедности, нищеты, выдвигаемый в социалистическом учении. Эта причина, по их убеждению, заключается не только в недостатках социально-экономического строя, но и в наличном, падшем и смертном, статусе мира. А значит, и активность объединенного человечества должна быть смещена с борьбы классовой, уничтожающей мнимых виновников несправедливости и несчастья, на борьбу с натуральными природными бедствиями: голодом, засухой, эпидемиями (их убийственный лик со всей ясностью обнажился в годы революции и Гражданской войны) и, наконец, с самой смертью.

Идею социального и экономического переустройства А.К. Горский и Н.А. Сетницкий рассматривали в активно-эволюционной, жизнетворческой перспективе, в свете конечных, метаисторических, религиозных целей и задач. Категорию труда они выводили из области политэкономии в сферу философской онтологии и антропологии, определяя труд как мироустроительную, целенаправленную, сознательно-творческую деятельность человека в бытии, носящую антиэнтропийный характер. В их сочинениях возникал образ планетарного и шире - «космического хозяйствования», целью которого является преображение земли, человека, Вселенной.

Стремясь внедрить в сознание своих современников федоровские мировоззренческие установки, переориентировать масштабное строитель- 
ство, разворачивавшееся в Советской России, с односторонне-социальных и классовых проблем на проблемы всечеловеческого и даже вселенского масштаба, А.К. Горский и Н.А. Сетницкий особенно внимательно присматривались к литературе, видя именно в ней ростки нового, планетарного миросознания. В первые пореволюционные годы преобразовательно-космические мотивы, образы творческой регуляции материи, мечты о будущем бессмертном человечестве, выходящем на просторы Вселенной, наполнили творчество поэтов самых разных течений: от деятелей группы «Кузница» и биокосмистов до раннего А. Платонова, С. Есенина, В. Хлебникова, В. Маяковского [5, с. 8-II]. Что касается А.М. Горького, то уже в его дореволюционном творчестве А.К. Горский увидел стремление открыть человеческой активности имморталистические перспективы. Он особенно акцентировал поэму «Человек», где рядом с образом Существа, стремящегося «вперед! и - выше!», встает подругой и помощницей Мысль, которая «в борьбу вступает и со Смертью»: «...ей, из животного создавшей Человека, ей, сотворившей множества богов, системы философские, науки - ключи к загадкам мира, - свободной и бессмертной Мысли, - противна и враждебна эта сила, бесплодная и часто глупо злая» [І8, т. 5, с. 364].

Поэму «Человек» А.К. Горский позднее определит как один из манифестов целостного, деятельного, творчески ориентированного сознания, которое призвана утвердить в мире Россия XX в., преодолевая те пессимистические тенденции, которые усилились в сознании европейского человечества после Первой мировой войны, в г920-I930-е гг. все чаще воспринимавшейся современниками философа как пролог к будущей тотальной схватке народов, к Армагеддону истории. В IV выпуске очерков «Николай Федорович Федоров и современность», названном «Острие мирового кризиса» (работа вышла в г933 г., хотя реально была написана в г927 г.), он затрагивал вопрос об угрозе всемирной войны, подчеркивая, что избежать этой угрозы можно лишь обращением на путь «всеобщего дела». Без радикальной умопремены цивилизация потребления и комфорта, овнешняющая человека, обращающая самые новейшие открытия науки и самые головокружительные достижения техники на потребу торгово-промышленному эгоизму, не видящая в экономике ойкономию, не подкрепляющая техническое развитие прогрессом нравственным, обречена на вечную рознь, а в перспективе - и на неизбежную гибель. Делая этот прогноз, А.К. Горский прямо ссылался на 
А.М. Горького: в предисловии к переводу книги Л.П. Локнера «Генри Форд и его корабль мира» (Л., г925) писатель пророчил европейскому региону, раздираемому внутренними противоречиями и международной враждой, новую мировую войну, которая, обращая себе на потребу все научные завоевания человечества, все новейшие технические средства, фактически уничтожит цивилизацию, обратит «в прах очаги европейской культуры и людей, тех, что не будут убиты, искалечены или повержены в безумие», превратит «в диких животных» [18, т. 24, с. 247]. Вплетая в свой текст строки из предисловия А.М. Горького, А.К. Горский проводил параллели между данной писателем картиной будущего европейского мира и той апокалипсической картиной, которая представлена в символическом сне героя «Преступления и наказания» о поразившей человечество моровой язве, о безумии и бешенстве, охватившем погрязших во зле людей. Сюда же привлекал и пророчества Н.Ф. Федорова о будущей «сциентифичной битве», которая неминуема для человечества, упорствующего на путях розни [35, т. I, с. I40].

Перед лицом «новой мировой войны» актуализируется, по мысли А.К. Горского, необходимость жизнеутверждающего смелого слова, громкого и твердого призыва, «течения встречного», которое могли бы воздвигнуть ведущие умы современности. Как в свое время Н.Ф. Федоров надеялся на Ф. Достоевского, Л. Толстого и В. Соловьева, что они выступят от своего имени с призывом к общему делу, так А.К. Горский и Н.А. Сетницкий в І920-е гг. стремились подвигнуть А.М. Горького заговорить об идеях Н.Ф. Федорова, для которого вопрос о преодолении небратского состояния мира был ключевым. Об их усилиях в этом направлении и о встречной реакции А.М. Горького нам уже приходилось писать [2, с. 508-515], останавливаться на данном сюжете здесь мы не будем, а сразу же перейдем к той интерпретации творчества Горького, которая была дана Горским уже после смерти писателя, в его литературно-философских заметках и набросках, и прежде всего в работе «Преодоление Фауста» (1939-1940).

\section{«Преодоление Фауста» как опыт литературно-философского синтеза. Идейный диалог А.К. Горского с современностью}

Подобно статьям и докладам А.К. Горского І920-х гг., посвященным А.С. Пушкину, Ф.М. Достоевскому, А.А. Блоку и др., работа «Преодоление Фауста» представляет собой единство филологического и философского 
дискурса, и одновременно здесь, как и в других текстах Горского, суждение о писателе и его образе мира соединено с собственным исповеданием веры. Философская декларация облекается в форму литературно-критической статьи, но такой, в которой разбор художественного текста подчинен авторскому антропологическому и историософскому замыслу. И в этом смысле «Преодоление Фауста» встает в ряд таких текстов, как «Несколько слов о поэме Гоголя: Похождения Чичикова, или Мертвые души» К.С. Аксакова, «Проективное определение литературы. О “Мертвых душах”, «“Фауст” Гёте и народная поэма о Фаусте» Н.Ф. Федорова, «Поэзия Ф.И. Тютчева» и «Лермонтов» В.С. Соловьева, полемическая по отношению ко второй соловьевской статье статья Д.С. Мережковского «Лермонтов - поэт сверхчеловечества» и его масштабная дилогия о Л.Н Толстом и Ф.М. Достоевском.

Во всех этих текстах слово писателя становится тем материалом, из которого растет и на котором утверждается, как на каменном основании, мысль философа. К.С. Аксаков видит в «Мертвых душах» возрождение древнего эпоса, способного к целокупному охвату мира и человека, и выходит, опираясь на этот тезис, к апологии соборности. Н.Ф. Федоров рассматривает гоголевский шедевр сквозь призму воскресительного долга. В.С. Соловьев прочитывает творчество М.Ю. Лермонтова на фоне своей полемики с ницшеанством, а Д.С. Мережковский, отталкиваясь от созданного им образа Л.Н. Толстого как «духовидца плоти» и Ф.М. Достоевского как «духовидца духа», выходит к идее «святой плоти», к чаянию просветления и одухотворения телесности [27, с. 348-349]. Подобно этим примерам А.К. Горский в «Преодолении Фауста» через разбор художественных образов и публицистических высказываний А.М. Горького представляет апологию деятельного, активно-творческого идеала, который, с его точки зрения, должен быть введен в современность.

Общая направленность работы «Преодоление Фауста» и ее пафос связаны с той установкой, которую выработали себе А.К. Горский и Н.А. Сетницкий весной 1937 г., когда первый только вернулся из лагеря, а второй, двумя годами ранее приехавший из Харбина, работал в Институте мирового хозяйства, не подозревая, что до ареста и смертельного приговора остается всего несколько месяцев. Говорить о темах и смыслах русской философии, тем более о представителях христианского ее крыла, к коим и принадлежал Н.Ф. Федоров, в условиях идеологического прессинга 
I930-х гг., тотального моноидеизма, напрямую было немыслимо. Но можно было попытаться заговорить на языке эпохи, используя ее лексику, однако полностью при этом подменяя понятия, точнее давая им совершенно иное раскрытие, иной смысловой горизонт. Так в свое время в І923 г. А.К. Горский, философы В.Н. Муравьев, Н.А. Сетницкий и инженер С.А. Бекнев работали над сборником «Трудоведение», представляя федоровскую тему в контексте и риторике звучавшей тогда идеи «научной организации труда», в результате чего идея НОТ обрела метафизическое измерение, была соотнесена с идеей антиэнтропийной сущности жизни и труда человека, расширилась до «организации мировоздействия» [I4, кн. I, с. 7ІІ; I5, с. I3-I9, 538-545]. И весной г937 г. они написали работу «Творческий марксизм и ликвидация хвостизма в биологии» (1937), где, взяв за отсчет фразу Сталина, прозвучавшую 3 августа I9I7 г. на VI съезде РСДРП(б): «Существует марксизм догматический и марксизм творческий. Я стою на почве последнего» [34, с. I87], дали свое определение творческого марксизма, наполнив это понятие федоровским, имморталистическим содержанием, трактуя его как активное мироотношение, выводящее к преобразовательному действию в природе и истории, направленное против смерти, требующее активного сопротивления ей [32].

В своем стремлении донести до современников смыслы «Философии общего дела» А.К. Горский решил двигаться через литературу. Это решение вызрело в нем еще в лагерный период, когда в маленьких тетрадках, выпущенных в Кеми, пересыльном пункте Соловецких лагерей, он писал заметки о современных писателях, вступая в заочный диалог с художниками слова, призывая их на «очную ставку» с современностью, требуя от них ответить на главный вопрос: как миру двигаться в будущее и как строить его, чтобы в перспективе истории утвердился рай, а не ад на земле [І4, кн. 2, c. 93-IOI]. А в последние пять лет жизни, когда философ поселился в Калуге, городе К.Э. Циолковского, диалог с литературой становится в центр его творчества. В письме О.Н. Сетницкой от 9 июня 1937 г. он сообщает о своей работе над А.М. Горьким, а параллельно над Корнеем Чуковским [I4, кн. 2, с. 53I]. Позднее присоединяет сюда Б. Пастернака, а затем расширяет диалог о будущем и на Серебряный, и на девятнадцатый век, создавая цикл «Песни без недомолвок», включающий в себя стихотворения русских классиков (М.Ю. Лермонтова, А.А. Фета, А.К. Толстого, А.А. Блока, Ф. Сологу- 
ба, А. Белого, Н.С. Гумилева, Б.Л. Пастернака и др.), дописанные им самим. Присоединяя к известным текстам свои «хвосты», А.К. Горский то прояснял смыслы, близкие ему самому, договаривая недосказанное, раскрывая жизнетворческий идеал в его полноте и объемности, то полемизировал с позицией лирического героя, особенно когда в его слове, как в блоковском «Ночь - как ночь, и улица пустынна. Так всегда», звучали ноты отчаяния и безнадежности [22].

В своей битве за образ будущего, А.К. Горский из писателей-современников берет в союзники А.М. Горького, из писателей-классиков А.С. Пушкина, подчеркивая, что Горький для двадцатого века - то же, что Пушкин - для девятнадцатого. Воскресительный пафос творчества А.С. Пушкина, который философ раскрывал в работе «Магический кристалл», написанной в I922 г. [I4, кн. I, с. 294-370], в набросках и заметках о Пушкине, сделанных в лагерной тетради «Творческая непрерывка» [I4, кн. 2, с. 16-32], а затем в год гоо-летия со дня смерти поэта, и имморталистический пафос творчества А.М. Горького, о котором он начинает писать в конце г930-х гг., в его представлении, сходятся, определяя новый мировоззренческий выбор - в пользу жизни, внутренне растущей, раскрывающейся во всей полноте, а главное - не идущей на компромисс с умалением и смертью.

В статье «Укрыватели убийц», написанной по поводу смерти А.М. Горького и знаменитого процесса г938 г., на котором в преднамеренном убийстве писателя были обвинены его секретарь П.П. Крючков, лечащие врачи, а также политические деятели Н.И. Бухарин, Г.Г. Ягода [8], А.К. Горский подчеркивал, что обвинять нужно не конкретных людей, а тот мировоззренческий пессимизм, ту торжествующую в сознании современного человека убежденность в неотвратимости и неизбежности смерти, о которой сам Горский и его друг Н.А. Сетницкий писали еще в I925 г. в работе «Смертобожничество». «Укрывателем» и «шефом убийц» является трусливый, бессильный человеческий ум, легко примиряющийся со смертью как «законом природы» [ı6, с. 7о]. Напротив, «целеустановка» А.М. Горького, лежащая в основании его понимания культуры и творчества, по мысли А.К. Горского, строится на «уверенности в принципиальной устранимости смерти, в возможность и надобности борьбы с умиранием до конияа, то есть до полной победы жизни, победы человека и человечества» [16, с. 6I]. В этом смысле он - продолжатель 
А.С. Пушкина, устремлявшегося к «высшей правде», к гармонизации бытия («Жизни даровать, о, лира, твое согласье захотел»), ко всецелому охвату реальности творческой мыслью и вдохновением, что, с точки зрения самого А.К. Горского, означало первый шаг на пути преображения бытия в благобытие, мира - в Царство Христово [І4, кн. 2, с. I9, 32].

\section{«Преодоление Фауста» и лагерная гётевиана первой половины г930-х гг.}

В работе «Преодоление Фауста» А.К. Горский будет сравнивать A.М. Горького с творцом, не менее мощным, олицетворявшим полноту художественных и духовных потенций европейской культуры: «Фигура Горького столь же монументальна и характерна для культурного перевала от I9-го столетия к 2о-му, как фигура Гёте, замыкающая І8-й век и открывающая дорогу к г9-му. Обоих художников роднят постоянные универсальные замыслы, стремление к охвату центральных научно-философских проблем, действенный интерес к культуре в самом широком смысле слова» [15, с. 9].

К фигуре Гёте А.К. Горский обратился еще в 1932 г. в статье «Света, больше света!», посвященной его гоо-летнему юбилею. Официальная советская критика одновременно и разоблачала «буржуазность», филистерство Гёте, и призывала к «критическому усвоению и переработке тех элементов творчества великого поэта эпохи Sturm und Drang, которые принадлежат будущему» [II], особенно выделяя в связи с последним предсмертный монолог Фауста: «Лишь тот свободной жизни властелин / Кто дни свои в борьбе проводит трудной» [Іо]. Герой гётевской трагедии трактовался как преобразователь мира, деятель, ведущий людей к счастью, находящий «решение загадки жизни в победоносной борьбе трудового коллектива» [2г]. Однако А.К. Горский, наследник русской религиозно-философской традиции, критичен к идее творческой активности, совершающейся вне поля веры. Знаменитая теза Фауста, провозглашающего началом всего не Слово, а Дело, вызывает спор мыслителя, который подчеркивает амбивалентность действия, лишенного религиозного основания, выбившего из-под себя евангельскую опору: «Деяние, очутившееся взамен Слова в начале бытия, мгновенно отражается в образе визжащего, мечущегося пуделя, с которым необходимо “делиться комнатой”. Пудель вырастает как бегемот, скалит пасть, наконец, испуганный видом Креста и Божьего огня, является из рассеявшегося тума- 
на в одежде странствующего схоласта, рекомендуясь как некое изначальное деятельное стремление. А именно “стремленье разрушать”. Ведь разрушение - тоже “деяние”» [І4, кн. 2, с. 79].

Примечательно, что тот же образ пуделя, воплощения темных, демонических сил, вырастающего сразу после того, как Фауст провозглашает примат Деяния над Словом, акцентирует А.А. Мейер в своих «Размышлениях при чтении “Фауста” , создававшихся, как и статья А.К. Горского, в лагере на Медвежьей горе. А.К. Горский акцентирует амбивалентность действия, основанного от божественной первоосновы, А.А. Мейер - призрачность реальности, отрекшейся от Слова, утратившей с ним животворную связь [26, с. 234-235], и оба сходятся в понимании того, что и Бытие, и Действие не могут иметь полноты вне Божества.

Ведущий публикатор и исследователь наследия А.Ф. Лосева Е.А. Тахо-Годи акцентирует одновременность обращения к фигуре Гёте сразу трех «сидельцев» Медвежьей горы - А.К. Горского, А.А. Мейера и А.Ф. Лосева, подчеркивая, что созданные в г933 г. тезисы философа могли быть связаны с контекстом обсуждения гётевской темы в лагерной среде [9, с. І67-І68]. Можно предположить, что статья «Света, больше света!» также связана с этими обсуждениями. Именно на фоне размышлений и заметок А.Ф. Лосева о свете и цвете у Гёте [24] обретает дополнительный смысловой объем название статьи А.К. Горского. Слова Гёте «Света, больше света!», сказанные на смертном одре, он трактует как утверждение онтологической правды Света, стоящего за Словом, того нетварного света, которым была исполнена фигура Христа, преобразившегося на горе Фавор, который стяжали монахи-исихасты в умной молитве и который осиял преп. Серафима Саровского, учившего о «стяжании Духа Святого» как «цели христианской жизни» [30].

Используя метод «медленного чтения», А.К. Горский рассматривает финальную сцену «Фауста», видя в ней разоблачение слепоты героя, иллюзорности его мысли и действия («в тот самый момент, как Фауст провозглашает необходимость ежеминутной борьбы, упорного боя за жизнь, жизнь у него отнимают без всякого боя» [I4, кн. 2, с. 8I]). И в то же время он пытается, опираясь на гётевскую трагедию, набросать «туманный чертеж возможности иного рода деяний» [І4, кн. 2, с. 87]. Каких? - об этом узнаем из рукописи работы «Преодоление “Фауста”, куда в переработанном виде вошла часть статьи «Света, больше света!» 


\section{«Фаустианская тема» в работе «Преодоление Фауста»}

Обе статьи - и «Света, больше света!», и «Преодоление Фауста» объединены темой гибели фаустовской культуры, впервые прозвучавшей у О. Шпенглера в трактате «Закат Европы», объявившего героя трагедии Гёте выражением и воплощением европейской души. А.К. Горский в своем анализе фаустианства отталкивается от идей О. Шпенглера, одновременно пытаясь понять, что именно в самой фаустовской душе способствовало ее надлому, в чем ахиллесова пята фаустианского типа сознания. И одновременно берет в союзники А.М. Горького, фигуру, как он сам указал, равновеликую немецкому поэту.

Он пытается понять, почему А.М. Горький, столь близкий Гёте по масштабу философской мысли о мире, так критичен к образу Фауста, ставшему для цивилизации и культуры Нового времени «наиболее полным олицетворением человека» [25]. Почему, возводя гётевский образ к народной легенде о Фаусте, писатель подчеркивает фиаско героя, продавшего душу дьяволу ради власти над тайнами природы, но не сумевшего достичь ни «всезнания», ни «бессмертия» [18, т. 24, с. 494].

Основная черта фаустианского сознания - активизм, неудержимое стремление к познанию мира и действию в нем. Но этот активизм, по A.M. Горькому, изначально ущербен, ибо сопряжен с индивидуализмом, с гордынным отрывом «я» от других, с тем «обособлением», в котором еще Ф.М. Достоевский увидел ахиллесову пяту современной личности. А главное, продолжает А.К. Горский мысль А.М. Горького, он трагичен, ибо при всех широковещательных лозунгах («Лишь тот достоин жизни и свободы, / Кто каждый день за них идет на бой») основан на убеждении в существовании роковых пределов жизни, в неустранимости смерти для человека и человечества.

Именно из сознания этих пределов вырастает, по мысли А.К. Горского, европейский пессимизм и ощущение заката Европы. Творческая активность западного человечества, основанная на индивидуализме, на утверждении человека мерой всех вещей, споткнулась о смертные границы и его собственной природы, и природы мира. Свобода личности обернулась иллюзией. А.К. Горский приводит знаковую цитату из О. Шпенглера: «К чему $<$...> употреблять сомнительное слово “свобода”? Мы отныне не свободны осуществить то или иное, но только необходимое, или ничто. Сожалеть и 
порицать не значит изменять. Рождение влечет за собой смерть, за юностью следует старость, жизни вообще присущза определенная форма и предельные границы ее длительности. В связи с этим отпадает целый ряд жизненных содержаний как невозможных. Об этом можно сожалеть и облечь это сожаление в форму пессимистической философии и лирики, но изменить это невозможно» [37, с. 42].

Коренящееся в глубинах фаустианской культуры и фаустианского типа человека преклонение перед наличной природой вещей, устроение которой противоречит разуму и нравственному чувству личности, примиренность со смертью позволяет А.К. Горскому сблизить фаустианство с мещанством. Эта на первый взгляд неожиданная параллель проясняется по ходу ее развертывания в тексте работы «Преодоление Фауста». А.К. Горский развивает трактовку мещанства, которая была представлена у А.И. Герцена и особенно у А.М. Горького, подробно останавливаясь на окуровском цикле. Мещанская - «окуровская» - философия есть философия пассивности, сна и метафизической скуки, это философия пределов, их же не прейдеши, философия примиренности со смертью, не допускающая даже тени иного выбора: «Всем делам - один конец. И ходя умрешь, и лежа умрешь» [I8, т. 9, с. 234].

И фаустианская индивидуалистическая активность, рвущаяся за пределы возможного, но одновременно ограничивающая этот порыв признанием неколебимости смерти, ее естественности для человека, и окуровская пассивность, стремление плыть по течению, своим итогом имеют одно: смерть, тесный гроб и могилу. Тот самый гроб, куда ложатся, «вытягивая ходилки», жители городка Окурова. Ту самую могилу, которую, по приказанию Мефистофеля, добросовестного служителя «имущему державу смерти», роют лемуры для Фауста.

А.К. Горский критикует «смертопоклонство» современной ему цивилизации, подчеркивая, что оно проникает в область не только мировоззрения, но и веры, и тогда смерть предстает не как «последний враг», но как блаженный переход в инобытие, в божественную потусторонность. Еще в работе «Смертобожничество» (I925) А.К. Горский и его друг и соавтор H.А. Сетницкий показали линии проникновения в христианское учение этой пассивной, обоготворяющей смерть установки. Философы настаивали на том, что смертность, стихийность и слепота не богоданны, противопо- 
ложны божественному основанию мира. Понимание смерти как врат чаемой Вечности столь же иллюзорно, как иллюзорна уверенность ослепшего Фауста, что «звон лопат» вокруг него - знак общей работы по созданию плотины морю («Здесь вся толпа мой замысел исполняет: / Она кладет предел морской волне, / С самой собою землю примиряет, / Грань строгую для моря создает»), в то время как на деле этот звон - звон могильщиков, готовящих его смертный час.

Фаустианство, по А.К. Горскому, есть порождение того же «лукавого и умного духа», «духа самоуничтожения и небытия» [19, c. 229], о котором говорит у Ф.М. Достоевского Великий Инквизитор Христу. Именно этот дух поселяет в человечество сознание неотвратимости конечной гибели, а значит, и парадоксальное, гартмановское стремление эту гибель ускорить. Мефистофель, отдающий приказ лемурам копать могилу Фаусту в то время, как ослепший герой грезит об осушении болота и положении предела морской стихии, прямо указывает на союз стихийного и смертного порядка природы с демоническим, злым началом мира:

Как ни трудись, плоды плохие!

Ведь с нами заодно стихии;

Уничтоженья ждет весь мир.

Об этом поистине смертоносном союзе А.К. Горский писал еще в І9Іо-е гг. в серии статей «Германизм и музыка», а спустя десятилетие в очерке «Острие мирового кризиса». Цитируя стихотворение К.К. Случевского «Мефистофель» - о «яде дурмана», напущенном злым соблазнителем в сердца людей, о «смраде тленья», смешавшемся «с жаждой идеала», о «празднике смерти», нагло включенном «в Четью-Минею», он говорил о смертобожничестве как о подмене христианского идеала, который есть воплощенная жизнь - жизнь целостная, преображенная, лишенная жала смерти [г4, кн. I, с. 790-79г]. Философ указывал на проникновение смертобожнических тенденций в трактовку последней книги Нового завета - «Откровения Иоанна Богослова»: не мотив сопротивления сил света противобожеским силам тьмы, не образ тысячелетнего царства Христова, преображенной и обновленной земли выдвигаются на первый план, но апостасийные образы Вавилона, Зверя из бездны, блудницы на Звере, 
а конечное обновление мира приобретает характер тотальной гибельной катастрофы. В свое время именно такой катастрофический сценарий истории отстаивал в полемике с Ф.М. Достоевским К.Н. Леонтьев, заявлявший, что «Христос проповедовал не гармонию всеобщую, мир всеобщий, а всеобщее разрушение», а значит, «все здешнее должно погибнуть» [23, с. I89]. А.К. Горский показывает, как тот же сценарий крепнет в современную ему эпоху, как нарастает в сознании человечества, вышедшего из катаклизма Первой мировой войны и революционных потрясений в России, убеждение в неизбежности для человечества войны и конечной катастрофы.

В работе «Преодоление Фауста», которая писалась в конце г930-х гг., религиозно-философские акценты, отчетливо ощутимые в очерке «Острие мирового кризиса», в статье «Света, больше света!», по понятным причинам были затушеваны автором. Но, не имея возможности в тексте, изначально предназначенном для печати, обращаться к активно-христианской линии мысли, А.К. Горский делал это прикровенно. Данная в работе «Преодоление Фауста» критика европейской философии, пронизанной духом пессимизма и катастрофизма, базируется именно на активно-христианском понимании путей философии и путей мира. Неотвратимость всеобщей гибели, подчеркивал А.К. Горский, является коренной чертой «фаустовского человека» и фаустианского сознания как такового. Герой фаустианского типа при всей его активности и декларативности не верит в возможность радикального расширения границ человеческого действия. Его мировоззренческая установка изначально пессимистична, соединена с ожиданием всеобщей гибели. Закономерным следствием подобного симбиоза является и гартмановское чаяние вселенского самоубийства человечества, и ницшеанское стремление «всем как одно целое пойти навстречу предстоящей гибели с трагическим умонастроением» [29, с. 352], и даже, как это ни парадоксально, идея героической смерти в бою, «погибели в борьбе с вражьей силой», которая есть не что иное, как выбор «достойной формы умирания» [15, с. 36]. Подкладка идеи героической смерти - все тот же историософский и онтологический пессимизм, все то же неверие в возможность для человека и человечества увидеть финалом земного существования что-нибудь кроме могилы и гроба.

А.К. Горский критикует позицию, которую разделяли многие его современники и известные умы XIX и XX вв., начиная с В.С. Соловьева и 
заканчивая И.А. Ильиным. Речь идет об апологии войны как своего рода духовной встряски заболоченного мира, покрывшегося ряской мещанства, погрязшего в тине обыденности. А.К. Горский против того, чтобы видеть в человеке существо, живущее и творящее из-под палки, побуждаемое к движению и активности лишь постоянной угрозой «утраты жизни и утраты свободы» [I5, c. 22]. Подобная точка зрения, предостерегает философ, приводит к парадоксальному выводу: и смерть, и страдания необходимы в экономии бытия, являются орудием гегелевского «лукавого разума» истории. «Если так, выходит, правы все те, кто хлопочет об умножении этих угроз, об увеличении количества оков, стеснений, смертей и смертельных опасностей. Правы апологеты войны, классового, расового и всякого иного гнета, рабства, эксплуатации и т. п.: ведь все это как-никак воспитает стойкость сопротивления, мужество и достоинство во всех или хотя бы немногих» [15, с. 22-23].

\section{Критика фашизма}

Оправдание смерти, ее целесообразности и нужности в бытии, когда смерть выступает как ассенизатор истории, кнут, подстегивающий человека и человечество в их движении по пространству земли, является, по тонкому прозрению А.К. Горского, той же разновидностью философии пределов, что и окуровское «во что ни верь, умрешь!». Именно эта философия, замечает философ, лежит в основе фашизма. Рассматривая феномен фашизма в свете своей критики смертобожнической фаустианской культуры, А.К. Горский подчеркивает, что он является последним словом этой культуры, симптомом ее заката, ее лебединой песнью. Говоря так, философ прямо апеллирует к А.М. Горькому, цитируя его определение фашизма как «порождения буржуазной культуры, находящейся уже в состоянии гниения и распада» [I8, т. 27, с. 453], как «раковой опухоли» на теле европейского человечества.

Культ Вагнера и Ницше в идеологии Третьего Рейха также обнажает, по мысли А.К. Горского, пессимистическую, пассивно-апокалиптическую установку, скрытую в подпочве идеологии национал-социализма. Убежденность в конечной гибели человечества соседствует с бестиализмом, с преклонением перед силой природы, более того, с сознательным следованием ей (отсюда культ расы и крови, идея отбора, селекции, уничтожения слабейших, борьбы и войны как способа утверждения сильной, перспективной 
расы). «Ни одна “идея”, - пишет А.К. Горский с сарказмом, комментируя “Майн кампф" Гитлера, - не вошла столь крепким клином в несложную голову незамысловатого автора, как убеждение в окончательной беспомощности человека перед лицом всемогущей природы; оно стало, можно сказать, основоположною заповедью этого корана Третьей Империи. “Тот, кто противится железной логике природы, восстает против основных законов человеческого существования... Я хорошо знаю это типичное, наглое и бессмысленное выражение: “Человек побеждает природу!” Миллионы людей, как попугаи, повторяют эту глупость и, в конце концов, начинают воображать, что они действительно победители природы” [15, c. 37]. А бессилие перед природой оборачивается в идеологии Третьего Рейха преклонением перед ней и эксплуатацией смерти как действенного орудия власти.

Фашизм вырастает на почве сознания непреодолимости смерти. «Панический культ “непобедимой” природы, романтики войны и мистики смерти - три коренных устоя фашизма» [15, с. 38]. Но именно поэтому борьба с ним не может строиться только на идее отпора, благородной ненависти к врагу. Об этом А.К. Горский будет неоднократно писать в годы, когда война придет на землю его отечества, выступая против призыва И.Г. Эренбурга «Убей немца!» Подобно тому как христианство учит различать зло и носителя зла, А.К. Горский настаивает на необходимости разводить фашистскую идеологию и зараженных ею людей. А главное - видеть то, что скрывается за идеологией: обожествление слепой, смертоносной силы природы, убежденность в бессилии перед ней, тщательно внушаемую «лукавым духом», «имущим державу смерти».

Мысль и творчество А.М. Горького стоят, по А.К. Горскому, в авангарде антифашистского сопротивления. В них звучит несмиренность со смертнической установкой сознания, последовательный призыв к активной борьбе с природной стихийностью. А.К. Горский подчеркивает религиозную ценность горьковской критики мещанства, «буржуазного гуманизма», который «все время пытался превознести и возвеличить ценность человека, увиливая при этом от категорического четкого ответа на крайне простой вопрос: чем же в конце концов должен быть этот хваленый “человек”: данником природы, пленником стихии или их повелителем и управителем?» [15, c. 4I]. Будучи сторонником активно-творческой веры, А.К. Горский говорит 
о правде неприятия А.М. Горьким пассивно-христианского упования на потусторонность бессмертия, подчеркивая, что это не христианство, а извращение христианства. Для А.К. Горского А.М. Горький глубинно религиозен, ибо не смиряется с падшим и смертным порядком природы, чувствует и сознает творческое призвание человека в бытии, подобно тому как сознавали это - но стоя на почве активного христианства - Н.Ф. Федоров, В.С. Соловьев, Н.А. Бердяев, С.Н. Булгаков. Именно А.К. Горький, прямо выдвигавший в ряде статей и выступлений идею борьбы со смертью и природной стихийностью, дает прочные основания сопротивления духу фашизма как духу пессимизма и катастрофизма, как законченному проявлению смертобожничества.

\section{«Преодоление Фауста» и идеал регуляции}

Выступая против трагического миросознания, возводящего идею всеобщей гибели в неотменимый закон, А.К. Горский еще в статьях, написанных в годы Первой мировой войны, противопоставил духу германизма, стоящему на этом миросознании, литургизм, основанный на идее преображения мира, активного соучастия человечества в созидании совершенного строя жизни. В работе «Преодоление Фауста» эта мысль получила новый идейный импульс. Против окуровской пассивности в отношении к миру, обратной стороной которой является фаустианская безбожная индивидуалистическая активность, в смертном мире изначально окрашенная трагически, философ выдвигал литургическое «общее дело», богочеловеческую «работу спасения». Эксплуатирующее, эгоистическое отношение к бытию, становящемуся лишь подножием проектов и планов самовластной титанической личности, заменялось у А.К. Горского регуляцией - в том смысле, который придавал этому понятию Н.Ф. Федоров. Регуляция - это «внесение в природу воли и разума» [7, с. 526], преодоление природного порядка существования, стоящего на борьбе, вытеснении и смерти, приведение природы в подобие Пресвятой Троицы, утверждение в ней закона соборности и любви.

Задавая вопрос: «Что должно стать нормой человеческого отношения к любой стихии: сознательное, разумное овладение этой стихией, или слепая, “безумная” ей отдача?», А.К. Горский апеллировал к выраженному у позднего А.М. Горького требованию активного отношения человека 
к миру, борьбы с природой, разумея, как уже было сказано, под «природой» не совокупность всего живого, но слепой, извращенный порядок существования. В статье «Преодоление Фауста» А.К. Горский цитирует строки из статьи А.М. Горького «О библиотеке поэта», в которой выдвигались новые творческие темы искусства: «Наше время включает в область поэзии совершенно новые темы, например, борьбу коллективно организованного разума против стихийных сил природы и против “стихийности” вообще» [І8, т. 26, с. 182]. Фраза А.М. Горького для него тем важнее, что сам А.К. Горский держит в уме определение искусства, данное Владимиром Соловьевым: быть словом об идеале, «пророчеством и связующим звеном между красотою природы и красотою будущей жизни» [33, с. 398]. Искусство рисует образ-проект преобразовательной работы человечества, человечество же совокупным трудом осуществляет этот проект.

Трактуя тезис А.М. Горького о борьбе с природой, А.К. Горский видит в этой борьбе не человекобожескую активность, как то склонны были утверждать адепты религиозного пессимизма и катастрофизма, а богочеловеческое дело спасения, религиозный долг человека. Ведь и Христос умножал хлебы, ходил по водам, утишал бури, исцелял больных, воскрешал умерших и заповедал это своим ученикам, говоря: «Дела, которые творю я и он (верующий в меня) сотворит, и больше сих сотворит» (Ин. I4: І2). Однако сотворить эти дела не способен одинокий фаустовский человек, даже если он гордынно полагает себя ницшеанским сверхчеловеком. Подобное под силу только творческой воле объединенного человечества, воле, идущей не против Бога, а вслед за Ним, отдающей себя благому делу «восстановления мира в то благолепие нетления, каким он был до падения» [35, T. I, c. 4OI].

Проповедовать в открытую это богочеловеческое соработничество в условиях воинствующего безбожия г930-х гг. было немыслимо. Однако донести до своих современников идею всечеловеческой преображающей мир активности А.К. Горский хотел и, безусловно, полагал своим долгом. И если в силу цензуры не мог говорить о религиозных основаниях идеи преодоления смерти, то заговорил об источных ее основаниях, тех, что лежали в основе мифологического, патриархального сознания, питали действие первобытного коллектива, который, в отличие от человека индустриальной цивилизации, отгородившегося от природы при помощи своих машин и ме- 
ханизмов и убежденного в своей - на деле иллюзорной - власти над ней, гораздо острее сознавал враждебную силу стихии и мечтал в сказках о живой и мертвой воде, ковре-самолете, сапогах-скороходах, т. е. о победе над временем и пространством. В таком повороте мысли А.М. Горький снова оказывался опорой размышлений философа. А.К. Горский апеллировал к статье «Разрушение личности», в которой говорилось о стремлении коллектива «воскресить отшедшего, оставить его в своей среде». Разбирая эту работу, он подчеркивал характерное для А.М. Горького утверждение источной связи личности и коллектива и сознание искаженности их взаимоотношений в эпоху Нового времени, где происходит обособление личности от коллективных энергий, ее самостийное утверждение в бытии и истории. Пути одиночной личности, пусть титанической, обладающей недюжинными задатками, но именно в силу своей обособленности от других обреченной на поражение, А.М. Горький противопоставляет путь общего делания, и в народном сознании многоученый Фауст проигрывает необразованному, но сметливому Пульчинелло-Петрушке. «Непобедимый герой народной комедии, - цитирует А.М. Горького А.К. Горский, - он побеждает всех и все: полицию, попов, даже черта и смерть, сам же остается. В грубом и наивном образе этом трудовой народ воплотил сам себя и свою веру в то, что именно он преодолеет все и всех» [18, т. 24, с. 494].

\section{Сказка А.М. Горького «Девушка и смерть» в контексте имморталистической темы}

Выше мы уже говорили об оценке А.К. Горским некрасовских «Коробейников»: выплеск коллективной народной души, «гудение всего народа» [14, кн. I, с. 22]. Спустя тридцать лет в работе «Преодоление Фауста» А.К. Горский характеризует раннюю сказку А.М. Горького «Девушка и смерть», видя в ней именно такой голос почвы, проявление энергии коллектива, силы народного сознания, сопротивляющегося смерти, верящего в силу разума, любви и природную сметку.

В г930-е гг. сказка А.М. Горького была актуализирована высказыванием И.В. Сталина: «Эта штука посильнее, чем Фауст Гёте. Любовь побеждает смерть». А.К. Горский подхватывает эту цитату и встраивает ее в контекст собственного философского слова, придав риторической, банальной фразе совершенно иной смысл и объем, трактуя ее в контексте фе- 
доровско-соловьевской апологии воскресительной силы любви. Любовь, если она не есть пустословие, должна побеждать смерть реальным деланием. Именно любовь, не смиряющаяся с фатальным исчезновением любимого существа, способна организовать вокруг призыва к преодолению смерти всю мощь научного знания и всю силу творческого воображения.

В отличие от писавших в г930-е гг. о сказке А.М. Горького, А.К. Горский не превозносит девушку, смело просящую Смерть об отсрочке во имя любви и в конце концов заставляющую ее переменить приговор: «Она живет слепым чувством: в лучшем случае пробужденное любовью творческое воображение в ней еще не перешло в творческую волю, не ищет путей к действию» [12, с. 89]. Тем более не впечатляет его возникающий в финале сказки образ Любви и Смерти как неразлучных сестер. Новаторство А.М. Горького А.К. Горский видит в ином: «Творческий эффект достигнут здесь ничуть не новой трактовкой любви, но только новой трактовкой смерти» [15, с. 66]. Она не страшна, не всесильна, она смертельно устала и буквально дышит на ладан. «Смерть - эта грозная, чудовищная, “неведомая и незнаемая” черная сила, перед которой так трепетали все поэты, полагая высшую храбрость лишь в “бестрепетной” отдаче себя могиле, - эта смерть у Горького впервые до конца расшифрована, антропоморфизирована, очеловечена, показана изнутри. Показана не как “сила природы”, а как слабость человека» [15, с. 66]. По мысли А.К. Горского, А.М. Горький сломал привычный механизм восприятия (и прославления) «“убийственной” и самоубийственной любви», тем самым задав вектор разрешения оппозиции «Любовь» - «Смерть» в ином направлении: не к симбиозу любви и смерти, а к «полной победе» любви через преодоление смерти [I5, c. 66-67].

\section{Попытки продвижения работы в печать}

А.К. Горский сознательно выделял те грани миросозерцания писателя, которые были близки активно-творческому пафосу мысли Н.Ф. Федорова и его самого, делая понимания и суждения А.М. Горького фундаментом собственных построений. При этом, разворачивая критику «смертобожнических» тенденций современного мира, размышляя об анастатических альтернативных - путях истории, он сознательно не оставлял зазора между своей позицией и позицией А.М. Горького, хотя это зазор был очевидным: А.К. Горский продолжал активно-христианскую линию русской мыс- 
ли, утверждавшую единство Божественной воли и человеческого усилия, А.М. Горький - склонялся к модели прометеистического активизма. Однако в работе «Преодоление Фауста» философ сознательно пошел на определенную идейную редукцию, ибо рассчитывал выйти с этой работой в печать.

Поводом стал конкурс на соискание Сталинской премии. Сбор произведений по направлению «Литературоведение» осуществлялся в Институте мировой литературы (ИМЛИ), и 28 сентября І940 г. А.К. Горский передал в ИМЛИ данную работу вместе с другой своей статьей - «Воинствующий оптимизм», название которой было взято из статьи А.М. Горького о В.И. Ленине. По мысли А.М. Горького, ленинский оптимизм был построен на «чувстве непримиримой, неугасимой вражды к несчастиям людей», на «вере в то, что несчастие не есть неустранимая основа бытия, а мерзость, которую люди могут отмести прочь от себя» [І8, т. I7, с. 24]. Именно такой тип оптимизма А.К. Горский находил в самом А.М. Горьком. Хрестоматийному афоризму Панглосса «Все к лучшему в этом лучшем из миров», воплощающему прекраснодушный, но пассивный и бездейственный оптимизм, писатель, по мысли А.К. Горского, противопоставил оптимизм «другого типа, честный, последовательный и действенный», устремляющий к преодолению смерти [16, с. 8o].

И «Воинствующий оптимизм», и «Преодоление Фауста» на конкурс так и не попали (А.К. Горский задержал отправку работ более чем на полмесяца), но были переданы в секцию изучения жизни и творчества А.М. Горького. Однако поддержки эти рукописи не нашли. В Московском архиве А.К. Горского и Н.А. Сетницкого сохранился ответ-отзыв Т.Л. Мотылевой, тогда - ученого секретаря ИМЛИ, составленный по поручению дирекции института. Отдавая дань эрудированности А.К. Горского, «основательному знакомству с творчеством Горького и мировой литературой», подчеркивая справедливость тезиса А.К. Горского об «активном, жизнеутверждающем гуманизме» и вере писателя «в безграничные силы и способности человека», обращая мыслителя к работам современных исследователей, Т.Л. Мотылева выражала категорическое несогласие с данной Горским через Горького трактовкой смерти [28, с. I]. А.К. Горский откликнулся обширным письмом, в котором объяснял замысел своих статей, отвечал на ряд возражений и замечаний, высказанных Т.Л. Мотылевой [І7], однако на продвижение статей в печать это не повлияло. 


\section{Заключение}

Несмотря на то что работа «Преодоление Фауста» так и не вышла в свет, оставшись, по образному выражению поэта Н.С. Тихонова, «в могиле стола», прикровенно она сыграла свою роль в становлении философского горьковедения. Сохраненная в составе архива А.К. Горского, она была перепечатана его духовной ученицей О.Н. Сетницкой, которая познакомила с ней ведущего исследователя творчества Н.Ф. Федорова С.Г. Семенову, выпустившую в 1977 г. в сборнике «Контекст» комментированную публикацию работы философа «“Фауст” Гете и народная поэма о Фаусте» [36], где был представлен еще один ракурс к теме религиозно-философской гётевианы. Трактовка горьковского иммортализма, данная А.К. Горским, оказала влияние на интерпретацию творчества А.М. Горького в статьях исследовательницы [5, с. 276-287; 6, с. 5I7-524], а сама работа «Преодоление Фауста», представлявшая пример философской критики, стала одним из побудительных импульсов к ее замыслу философии русской литературы, вылившемуся в книги «Преодоление трагедии: “Вечные вопросы в литературе” (М., І989), «Метафизика русской литературы» (В 2 т. М., 2004) и др. 


\section{Список литературы}

\section{Исследования}

I Гачева А.Г. «Перед лицом войны и смерти...». Тема войны в поэтическом и философском наследии Александра Горского конца І930-х - начала г940-х годов // Человек и война / отв. ред. С.А. Никольский. М.: Голос, 2020. С. 303-339.

2 М. Горький и мир философских идей Н.Ф. Федорова (переписка с А.К. Горским и Н.А. Сетницким) / вступ. ст., публ., подгот. текста, примеч. И.А. Бочаровой и А.Г. Гачевой // М. Горький и его корреспонденты. М.: ИМЛИ РАН, 2005. C. $501-563$.

3 Макаров В.Г. Архивные тайны: философы и власть. Александр Горский: судьба, покалеченная «по праву власти» // Вопросы философии. 2002. № 8. С. 98-Із33. Русская философия и литература: пути взаимодействия / отв. ред. и сост. Е.А. Тахо-Годи. М.: Водолей, 20I8. 600 с. (Серия «Русская литература и философия: пути взаимодействия». Вып. І)

5 Семенова С.Г. Русская поэзия и проза г920-г930-х годов. Поэтика - Видение мира - Философия. М.: ИМЛИ РАН, Наследие, 200I. 590 с.

6 Семенова С.Г. Русская литература XIX-XX вв.: От поэтики к миропониманию. М.: Академический проект; Парадигма, 20I6. 890 с.

7 Семенова С.Г. Философ будущего: Николай Федоров. М.: Академический проект; Парадигма, 2019. 638 с.

8 Тайна смерти Максима Горького. Документы, факты, версии / отв. ред. Л.А. Спиридонова. М.: АСТ, 20I7. 464 с.

9 Тахо-Годи Е.А. А.Ф. Лосев о гётевском учении о цвете, трагедии «Фауст» и романе «Страдания юного Вертера» // Вопросы философии. 2019. № 9. С. I62-I72. DOI: I0.31857/So04287440006328-5 


\section{Источники}

Iо Бедный Демьян. «Гретхен из Таннрода», или Социальный внутренний мир Германии // Правда. I932. 22 марта. № 8I. Вечер памяти Гёте // Известия. 1932. 24 марта. № 83.

I2 Вселенское дело в прошлом // Н.Ф. Федоров: pro et contra. М.: РХГА, 2008. Кн. 2. С. 364-370.

I3 Горский А.К. Николай Федорович Федоров и современность // Н.Ф. Федоров: pro et contra. М.: РХГИ, 2004. Кн. І. С. 518-658.

I 4 Горский А.К. Сочинения и письма: в 2 кн. / вступ. ст., сост., подгот. текста, коммент. А.Г. Гачевой. М.: ИМЛИ РАН, 2018.

I5 Горский А.К. Преодоление Фауста. Машинопись. I939-I940 // Московский архив А.К. Горского и Н.А. Сетницкого (Частное собрание). гоз с.

I6 Горский А.К. Укрыватели убийц (псевд.: А. Мыславский). Машинопись. 1938 // Московский архив А.К. Горского и Н.А. Сетницкого (Частное собрание). $2 \mathrm{I} 2 \mathrm{c}$.

I7 Горский А.К. Письмо-ответ Т.Л. Мотылевой. І5 мая І94I // Московский архив А.К. Горского и Н.А. Сетницкого (Частное собрание). 38 с.

I8 Горький М. Собр. соч.: в 30 т. М.: ГИХЛ, І949-І955.

I9 Достоевский Ф.М. Полн. собр. соч.: в 30 т. Л.: Наука, І976. Т. І4. 5 І2 с.

20 Из истории философско-эстетической мысли І920-І930-х гг. М.: ИМЛИ РАН, 2003. Вып. г: Н.А. Сетницкий / сост. Е.Н. Берковской (Сетницкой), А.Г. Гачевой. $624 \mathrm{c}$.

2 I Каменев Л.Б. Гёте и мы // Известия. І932. 22 марта. № 8I.

22 «Комическое как врата вечного»: А.К. Горский. Песни без недомолвок / вступ. ст., подгот. текста, публ., примеч. А.Г. Гачевой // Комическое в русской литератуpe ХХ века. М.: ИМЛИ РАН, 20I4. С. 4І8-498.

23 Леонтьев К.Н. Собр. соч.: в г2 т. М.: В.М. Саблин, г9г2. Т. 8. 357 с.

24 Лосев А.Ф. Учение Гете о цветах. Замечание о «Вертере» Гете (Научная подготовка текста Е.А. Тахо-Годи) // Вопросы философии. 2019. № 9. С. I73-184.

25 Манн Г. В защиту культуры. М.: Радуга, І986. 4І2 с.

26 Мейер А.А. Размышления при чтении «Фауста» // Мейер A.A. Oeuvre philosophique. Paris: La Presse Libre, I982. С. 235-377.

27 Мережковский Д. Л. Толстой и Достоевский. Вечные спутники. М.: Республика, I995. $624 \mathrm{c}$.

28 Мотылева Т.Л. [Письмо А.К. Горскому]. 27 января І94I // Московский архив А.К. Горского и Н.А. Сетницкого (Частное собрание). 2 с.

29 Ницше Ф. Полн. собр. соч.: Несвоевременные размышления; Из посмертных произведений (І873-І875); «Мы филологи» / под ред. С. Франка и Г. Рачинского; [Предисл.: С. Франк]. М.: Моск. кн-во, г909. 426 с.

30 О цели жизни нашей христианской. Беседа преп. Серафима с Н.А. Мотовиловым. Киев: Киево-Печерская Успенская Лавра, 2013. 82 с. 
3I Сетницкий Н.А. СССР, Китай и Япония: Начальные пути регуляции // Известия Юридического факультета. Харбин, г933. Т. го. С. 187-247.

32 Сетниикий Н.А., Горский А.К. Творческий марксизм и ликвидация хвостизма в биологии. Машинопись. 1937 // Московский архив А.К. Горского и Н.А. Сетницкого (Частное собрание). $36 \mathrm{c.}$

33 Соловъев В.С. Соч.: в 2 т. М.: Мысль, І988. Т. 2. 822 с.

34 Сталин И.В. Сочинения. М.: ОГИЗ; Гос. изд-во полит. лит., І946. Т. 3. 428 с.

35 Федоров Н.Ф. Собр. соч.: в 4 т. М.: Издат. группа «Прогресс»; Традиция, 1995I999.

36 Федоров Н.Ф. «Фауст» Гете и народная легенда о Фаусте / предисл., публ., коммент. С.Г. Семеновой // Контекст - I975. М.: Наука, г977. С. 315-343.

37 Шиенглер О. Причинность и судьба. Закат Европы. Пб.: Академия, г923. Т. г. Ч. г / пер. с нем. под ред. А.А. Франковского. 2 І2 с. 


\section{References}

I Gacheva, A.G. “'Pered litsom voiny i smerti...'. Tema voiny v poeticheskom i filosofskom nasledii Aleksandra Gorskogo kontsa I930-kh - nachala I940-kh godov” [“Facing War and Death: War Theme in Alexander Gorsky's Poetic and Philosophical Works (Late I930s - Early I940s)"]. Chelovek i voina [Man and War]. Moscow, Golos Publ., 2020, pp. 303-339. (In Russ.).

2 "M. Gor'kii i mir filosofskikh idei N.F. Fedorova (perepiska s A.K. Gorskim i N.A. Setnitskim)” [“M. Gorky and the World of Philosophical Ideas by N.F. Fedorov (Correspondence with A.K. Gorsky and N.A. Setnitsky)"]. M. Gor'kii i ego korrespondenty [M. Gorky and his Correspondents]. Moscow, IWL RAS Publ., 2005, pp. 5OI-563. (In Russ.).

3 Makarov, V.G. “Arkhivnye tainy: filosofy i vlast'. Aleksandr Gorskii: sud'ba, pokalechennaia "po pravu vlasti” ["Archival Secrets: Philosophers and Power. Alexander Gorsky: Life as Destroyed "by the Right of Power"]. Voprosy filosofii, no. 8, 2002, pp. 98-I33. (In Russ.).

4 Takho-Godi, E.A., editor. Russkaia filosofiia i literatura: puti vzaimodeistviia [Russian Philosophy and Literature: Ways of Interaction]. Moscow, Vodolei Publ., 20I8. 600 p. (In Russ.).

5 Semenova, S.G. Russkaia poeziia i proza 1920-1930-kh godov. Poetika - Videnie mira Filosofiia [Russian Poetry and Prose of the I920s-I930s. Poetics -Vision of the WorldPhilosophy]. Moscow, IWL RAS Publ., Nasledie Publ., 200I. 590 p. (In Russ.).

6 Semenova, S.G. Russkaia literatura XIX-XX vv.: Ot poetiki k miroponimaniiu [Russian Literature of the $19^{\text {th }}-20^{\text {th }}$ centuries: From the Poetics to the Worldview]. Moscow, Akademicheskii proekt Publ.; Paradigma Publ., 2016. 890 p. (In Russ.). Semenova, S.G. Filosof budushchego: Nikolai Fedorov [The Philosopher of the Future: Nikolay Fedorov]. Moscow, Akademicheskii proekt Publ.; Paradigma Publ., 20I9. 638 p. (In Russ.)

8 Spiridonova, L.A., editor. Taina smerti Maksima Gor'kogo. Dokumenty, fakty, versii [The Secret of Maxim Gorky's Death. Documents, Facts, Versions]. Moscow, AST Publ., 2017. 464 p. (In Russ.)

9 Takho-Godi, E.A. "Losev o getevskom uchenii o tsvete, tragedii 'Faust' i romane 'Stradaniia iunogo Vertera'." [“Alexey F. Losev on Goethe's Theory of Colors, the Tragedy 'Faust' and the Novel 'The Sorrows of Young Werther'.”]. Voprosy Filosofii, vol. 9, 20I9, pp. I62-I72. DOI: I0.31857/Soo4287440006328-5 (In Russ.) 